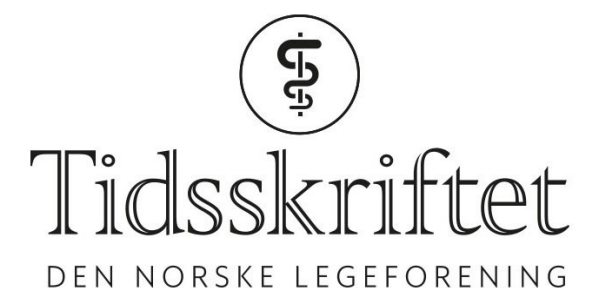

DEN NORSKE LEGEFORENING

\title{
Berekraft og bunad - aukande skilnader i norsk fødselshjelp?
}

LEDER

HILDE ENGJOM

E-post: hilde.engjom@gmail.com

Hilde Engjom er ph.d. og gynekolog ved Kvinneklinikken, Haukeland universitetssjukehus. Ho leia utval for menneskerettar, klima og global helse i Legeforeininga 2007-16.

Forfattaren har fylt ut ICMJE-skjemaet og oppgir ingen interessekonfliktar.

Folkerørsla Bunadsgeriljaen målber uro for opplevde skilnader i fødetilbodet og protest mot nye nedskjeringar. Verkemidla og kommunikasjonsforma er forfriskande nye, men dei samsvarer med bodskap frå forskarar og fagfolk.

FN sine berekraftsmål legg særskilt vekt på betre kvinne-barn-helse og på reduksjon av ulikskap i fordeling av helse (1). Kvinnene si deltaking står sentralt i utforminga av eit godt fødetilbod (2). Institusjonar i nærområdet spelar ei rolle både for helsehjelpa ved sjølve fødselen og i tida før og etter. I USA førte stenging av fødeinstitusjonar i distriktsfylke til fleire fødslar i helseinstitusjonar utan eit etablert fødetilbod og til reduksjon av oppfølging i svangerskapet (3). På leiarplass uttrykte JAMA uro for at kvinner og familiar i distrikta fekk dårlegare tilgang til helsehjelp av tilstrekkeleg kvalitet (4).

Rett behandling til rett tid er målet for fødselsomsorga (5). Barrierar undervegs i forløpet påverkar i kva grad dette målet vert nådd (6). I Noreg har lang reisetid til næraste fødeinstitusjon vore knytt til auka risiko for kvinna og barnet, og vi har sett aukande geografiske skilnader (7-9).

I Noreg har lang reisetid til næraste fødeinstitusjon vore knytt til auka risiko for kvinna og barnet

Dei fleste kvinner har normale svangerskap og føder friske barn. Få kvinner og barn vert alvorleg sjuke eller døyr i Noreg. Kvifor er det viktig å undersøke sjeldsynte hendingar? Systematisk gjennomgang av hendingsforløp ved alvorleg sjukdom og død kan både påvise svikt og kartlegge faktorar som betrar helseutfall (10).

Betra gjennomsnittstal i mødre- og nyføddhelse kan dekke over aukande absolutte og relative skilnader mellom land og innan ulike grupper i folkesetnaden. Rutinestatistikk vil sjeldan vere tilstrekkeleg til å vise slike skilnader. Vi treng pålitelege data og særskilde analysar for sårbare grupper, mellom anna geografi, etnisitet, utdanning og religion (2, 5, 11). Det er utarbeidd ei internasjonal rettleiing for forsking med definisjonar og vurderingar av urettvise skilnader i helse (12). Rettleiinga er oversiktleg og klart formulert, og definisjonen av urettvise skilnader i helse klargjer vesentlege premiss for politisk ordskifte og prioriteringar. Endringar i fødselsomsorga som forsterkar barrierar for sårbare grupper, 
vil motverke målet om likeverdige helsetenester. Slike endringar kan dermed auke urettvis ulikskap i helse, mellom anna ved lengre reisetid (6). Sjølv behandling ved store fødeinstitusjonar ser ikkje ut til å vege opp for ulempene ved lang reisetid (9).

Lønner det seg å spare pengar på fødselsomsorg? I EU var reduksjon i offentlege løyvingar til helse knytt til auka mødredødelegheit (13). JAMA kritiserer innsatsstyrt finansiering i fødselsomsorg (4). Det er i alle høve viktig med eit godt kunnskapsgrunnlag og eit sakleg ordskifte som tek med og belyser både gode erfaringar og uro.

\section{LITTERATUR:}

1. FN. Agenda for Sustainable Development 2015.

https://www.un.org/sustainabledevelopment/sustainable-development-goals/ Lest 19.11.2019.

2. Shaw D, Guise JM, Shah N et al. Drivers of maternity care in high-income countries: can health systems support woman-centred care? Lancet 2016; 388: 2282-95. [PubMed][CrossRef]

3. Kozhimannil KB, Hung P, Henning-Smith C et al. Association Between Loss of Hospital-Based Obstetric Services and Birth Outcomes in Rural Counties in the United States. JAMA 2018; 319: 1239-47. [PubMed][CrossRef]

4. Shah NT. Eroding Access and Quality of Childbirth Care in Rural US Counties. JAMA 2018; 319: 1203-4. [PubMed][CrossRef]

5. Howell EA, Zeitlin J. Quality of Care and Disparities in Obstetrics. Obstet Gynecol Clin North Am 2017; 44: 13-25. [PubMed][CrossRef]

6. Bærøe K, Kaur J, Radhakrishnan K. Lik tilgang og likeverdige helsetjenester. I: Aasen H, Bringedal B, Bærøe K et al, red. Prioritering, styring og likebehandling. Oslo: Cappelen Damm, 2018: 57-81.

7. Engjom HM, Morken NH, Norheim OF et al. Availability and access in modern obstetric care: a retrospective population-based study. BJOG 2014; 121: 290-9. [PubMed][CrossRef]

8. Engjom HM, Morken NH, Høydahl E et al. Increased risk of peripartum perinatal mortality in unplanned births outside an institution: a retrospective population-based study. Am J Obstet Gynecol 2017; 217: 210.e1-12. [PubMed][CrossRef]

9. Engjom HM, Morken NH, Høydahl E et al. Risk of eclampsia or HELLP-syndrome by institutions availability and place of delivery. Pregnancy Hypertens 2018; 14: 1-8. [PubMed][CrossRef]

10. Conti-Ramsden F, Knight M, Green M et al. Reducing maternal deaths from hypertensive disorders: learning from confidential inquiries. BMJ 2019;364: 1230. [PubMed][CrossRef]

11. O'Neill J, Tabish H, Welch V et al. Applying an equity lens to interventions: using PROGRESS ensures consideration of socially stratifying factors to illuminate inequities in health. J Clin Epidemiol 2014; 67: 56-64. [PubMed][CrossRef]

12. Welch VA, Norheim OF, Jull J et al. CONSORT-Equity 2017 extension and elaboration for better reporting of health equity in randomised trials. BMJ 2017; 359: j5085. [PubMed][CrossRef]

13. Maruthappu M, Ng KY, Williams C et al. The association between government healthcare spending and maternal mortality in the European Union, 1981-2010: a retrospective study. BJOG 2015; 122:1216-24. [PubMed][CrossRef]

Publisert: 2. desember 2019. Tidsskr Nor Legeforen. DOI: 10.4045/tidsskr.19.0663

(C) Tidsskrift for Den norske legeforening 2020. Lastet ned fra tidsskriftet.no 